\title{
Sob o signo do moderno cultivo: Estado imperial e agricultura na Amazônia
}

\author{
Francivaldo Alves Nunes \\ francivaldonunes@yahoo.com.br \\ Tese de Doutorado \\ Programa de Pós-Graduação em História \\ Universidade Federal Fluminense \\ Niterói (RJ) 2011
}

\begin{abstract}
As dimensões tomadas pela agricultura na Amazônia brasileira durante o Império, a partir do final da década de 1830, é o objeto central de análise desta tese. Buscamos, no entanto, o entendimento desta questão na heterogeneidade das interpretações, o que nos permitiu compreender que a atividade agrícola extrapolava os limites de uma prática econômica. Diante de uma discussão observada na imprensa e em documentos e pronunciamentos oficiais, e que suscitou diversas e diferentes interpretações, construímos uma proposição de análise que observa a agricultura para além de fenômenos relativos à produção, distribuição e consumo, ou ainda das rendas que poderiam gerar com a comercialização de seus produtos. Para a Amazônia, e isto toma uma dimensão maior do que para outras regiões do país, a agricultura se constituiu, nestas interpretações, como atividade moralizadora, disciplinadora, capaz de assegurar a constituição de propriedades e o povoamento regular, além do que possibilitaria a implantação de um modo de vida interpretado como civilizado e moderno. $\bigcirc$ caminho percorrido para este entendimento passou, necessariamente, pela compreensão de que os discursos construídos em torno da agricultura estavam associados às políticas de atuação do governo imperial, às contraposições entre as práticas de cultivo, às ações de auxílio e melhoramento agrícola, às políticas de colonização voltadas para o imigrante estrangeiro, aos indígenas e às práticas de aproveitamento do colono nacional, e que tinham no Estado brasileiro, a partir da articulação com as forças políticas da região amazônica, seu executor.
\end{abstract}

